\title{
SEMIOTIKA MITOLOGIS SEBUAH TINJAUAN AWAL BAGI ANALISIS SEMIOTIKA BARTHESIAN
}

\author{
Noveri Faikar Urfan
}

Universitas Teknologi Yogyakarta
Email: veriurfan@ gmail.com

\begin{abstract}
Roland Barthes is widely known as a semiotic figure who succeeded in renewing the thoughts of his predecessor Ferdinand de Saussure by introducing the concept of myth. Myth is a second level of signification system, which is built from reading the first level sign. Barthes considers that the reading of signs does not stop at the level of denotative meaning, but also needs to be directed to probe the connotative meaning that is hidden or which is often unconscious behind the object. Reading the signs to the level of myth is also an attempt to dismantle the existence of ideology. Ideology in the context of reading signs is interpreted as a forced meaning to be accepted as something natural. In the end, reading the signs in Roland Barthes's approach challenges us to apply them to reading contemporary objects such as advertising, photography, film and others. Sign readers are challenged to combine interpretive models on two levels, namely reading denotative meanings in reading language levels and connotative meanings in reading mythical levels.
\end{abstract}

Keywords: Roland Barthes, Semiotic, Significancy System, Myth

\section{A. PENDAHULUAN}

\section{Roland Barthes dan Mitologi}

Roland Barthes (1915-1980) dikenal luas sebagai tokoh utama kajian semiotika pasca strukturalisme yang melampaui pendahulunya Ferdinand de Saussure. Tahun 1956, Barthes telah membaca buku babon strukturalisme karya Saussure, Course in General Linguistics (Kursus tentang Linguistik Umum), yang kemudian menginspirasinya untuk melahirkan otokritik bagi pemikiran Saussure melalui sebuah buku kecil di tahun 1964, berjudul Elements de Semiologie (Beberapa Unsur Semiologi). Dari karya itu, Barthes tampak ingin melampaui pemikiran Saussure dengan menyatakan bahwa semiologi adalah ilmu yang tentatif atau sementara, sebab bahasa telah bergerak lebih jauh dengan munculnya sistem tanda di luar pengertian bahasa yang dipahami pada umumnya. Untuk menegaskan hal itu, Barthes menyoroti munculnya sistem tanda campuran seperti dalam komik, iklan, foto berita, film bioskop, yang memadukan antara bahasa ujaran dengan bahasa visual. Maka, ilmu tanda umum atau prinsip baku tentang keberlakuan sistem tanda yang bisa diterapkan dalam kondisi apapun -sebagaimana yang sudah dibangun oleh Saussure- harus dikembangkan lebih jauh agar mampu membaca variasi sistem tanda dalam kemajuan fenomena bahasa kontemporer.

Pemikiran Roland Barthes terus berkembang dengan ciri khasnya yang gemar menyoroti halhal sepele dalam dunia keseharian, seperti pertandingan gulat, budaya makan steik, minum anggur dan majalah usang yang tergeletak di tempat potong rambut. Barthes mengamatinya dengan tanpa menafikan kedalaman makna dari sesuatu yang sering dianggap remeh itu. Amatan Barthes pada hal- 
hal sederhana dunia keseharian lantas menemukan arti pentingnya saat orang-orang mulai mengenal luas tulisannya melalui buku Mythologies (1972), di mana gagasan orisinalnya tentang mitologi muncul. Dalam gagasannya tentang mitologi, Barthes mencoba mengarahkan pemaknaan tanda pada sebuah interpretasi kultural yang luas.

Dalam interpretasi atas steik dan anggur misalnya, Barthes menganggap bahwa orang-orang tidak hanya sekedar menyantap dan menikmati rasanya, tetapi juga menikmati gagasan atau ide di balik cita rasa steik dan anggur ${ }^{1}$. Bukankah ketika orang menyantap sepotong steik yang terhidang di atas piring, mereka juga merasakan sensasi lahapnya menyantap makanan sebagai representasi atas totalitas kenikmatan hidup, kekuatan dan gairah. Begitu juga dengan meminum anggur yang bukan hanya soal rasa, namun juga tentang citra visual gelas yang berkilau, warna likuid, dan cita rasa yang merepresentasikan gaya hidup santai, elegan atau bahkan citra minor tentang perilaku mabuk yang memalukan. Maka, memakan steik dan meminum anggur adalah lebih dari sekedar praktik biasa, melainkan juga sebuah ritual untuk menjadikan tanda (sign) merepresentasikan makna kultural, dengan kata lain menjadikan sepring steik dan segelas anggur merepresentasikan adanaya mitologi ke-Angguran dan ke-Steik-an di dalam masyarakat.

Perlu dijelaskan pula kepada pembaca bahwa pemikiran Roland Barthes tidaklah stagnan, melainkan dinamis sepanjang karir intelektualnya. Untuk itu penulis perlu memberikan sejumlah batasan agar mendapatkan posisi yang jelas dalam konfigurasi pemikiran Barthes. Bila ditelusuri, pemikiran Barthes tentang mitos bisa dibaca dalam buku Mythologies yang terbit pertamakali dalam Bahasa Prancis pada tahun 1957 sedangkan edisi Bahasa Inggrisnya terbit tahun 1977. Pemikiran tentang mitos sebenarnya berada dalam posisi masa awal dan pertengahan karir intelektualnya, dalam posisi ini Barthes punya karakter pemikiran yang khas di mana ia mencoba menjembatani model semiologi struktural dengan post-struktural, artinya Barthes menganggap bahwa analisis struktural terhadap objek dianggap penting sebagai materialitas terbentuknya wacana atau konotosi yang melampaui struktur.

Perpaduan antara analisis struktural dan wacana itu nantinya akan mulai ditinggalkan oleh Barthes dalam karya-karya terakhirnya, misalnya dalam Camera Lucida (1980). Dalam karya itu, Barthes justru menggunakan pendekatan fenomenologi untuk melihat objek fotografi, yang akhirnya justru mengabaikan pentingnya analisis struktural. Akan tetapi, dalam The Photographic Message yang ditulisnya lebih awal, yaitu tahun 1961, Barthes masih sangat mementingkan struktur bahasa foto sebagai bahan dasar pembentukan makna tingkat kedua. Maka, penulis akan mengatakan bahwa posisi tulisan ini ada di dalam konteks pemikiran Barthes di mana analisis struktur masih dianggap penting sebagai pintu masuk menuju wacana, atau dalam terminologi analisis semiologi Barthes disebut mitos. Bagaimana menggali pemikiran Barthes dalam posisi ini, setidaknya dua karya utama Barthes yaitu Mythologies dan Image, Music, Text bisa menjadi rujukan. Dua karya ini masing-masing terbit dalam

\footnotetext{
${ }^{1}$ Lih. Esai Barthes, Wine and Milk dan Steik and Chips dalam Mythologies (1972).
} 
edisi Bahasa Inggris tahun 1972 dan 1977, dengan pengecualian pada Image, Music, Text, buku ini adalah kumpulan esai-esai penting Barthes dari 1962-1970, yang dikumpulkan dan diterjemahkan oleh Stephen Heath.

Pemikiran Barthes tentang mitos, bisa dibaca dalam esai Myth Today yang termuat menjelang halaman-halaman akhir Mythologies. Myth today adalah esai paling penting sebab di sanalah penjelasan mengenai mitos bisa dibaca. Sementara Image, Music, Text, terutama dua esai pertamanya, yaitu The Photographic Message dan Rhetoric of The Image, memiliki kedalaman analisis dalam pelibatan pesan linguistik terhadap objek fotografi dan iklan. Akan penulis tambahkan juga sebagai sumber dalam artikel ini, esai Barthes dalam bukunya S/Z yang terbit pertamakali tahun 1973. Dalam S/Z terdapat sebuah konsep kunci yaitu lexsias atau unit-unit pembacaan tanda, yang akan memudahkan kita dalam melakukan analisis objek dengan memecahnya pada unit-unit pembacaan tertentu. Berdasarkan sumber-sumber tersebut, tulisan ini mencoba memetakan pemikiran Barthes tentang mitos dan menerapkannya dalam beberapa objek khususnya foto dan iklan. Dengan sumber yang amat terbatas itu, penulis berharap tulisan ini bisa memancing adanya penelusuran yang lebih mendalam pada kajian semiotika Barthesian.

\section{Mitos dan Sistem Signifikasi}

Kemunculan mitologi dalam objek-objek keseharian, menjadi semangat atas lahirnya model baru dalam sistem pembacaan tanda bahasa yang diajukan oleh Barthes. Tidak seperti Saussure yang berhenti pada satu tingkat sistem signifikasi, menurut Barthes, sistem interpretasi tanda terdiri atas dua level: pertama, level bahasa (language) untuk menunjukkan makna harifiah yang merujuk pada pemikiran Saussure tentang ketetapan makna sebagai hasil konvensi, kedua, adalah level mitos (myth) yang merujuk pada gagasannya sendiri tentang interpretasi kultural terhadap tanda, yang merepresentasikan kultur, atau mitologi di balik objek. Model interpretasi tanda dalam dua tingkat ini, ia kemukakan dalam tulisannya Myth Today (1972) dengan menyertakan gambar kerangka sebagai berikut:

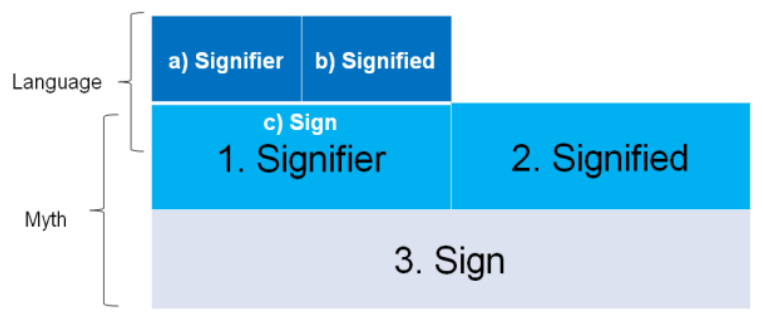

Gambar.1. Kerangka sistem signifikasi dua tingkat Roland Barthes, dalam Mythologies (1972:113).

Dari model signifikasi (signification) inilah, konsep mitos (myth) muncul dengan apa yang disebutnya sebagai second-order of semiologycal system atau tingkat kedua dalam sistem pembacaan tanda. Mitos dalam pembacaan tanda model ini, terlebih dahulu disusun dari tingkat pertama (firstorder of semiologycal system) yaitu tingkat bahasa (language), di mana aspek material tanda yang disebut penanda (signfier) dan aspek mental atau petanda (signified) membentuk tanda (sign) yang 
bersifat denotatif (denotation) atau harfiah. Tanda denotasi atau makna harfiah dalam signifikasi tingkat bahasa kemudian menjadi materi pembentuk signifikasi tingkat kedua dengan kata lain, ia berubah posisi atau terdeformasi menjadi penanda bagi sistem tingkat kedua. Penanda mitos kemudian dikaitkan dengan petanda mitos, sehingga mitos secara formatif berdiri sebagai bahasa di tingkat yang kedua, dengan kata lain mitos bisa disebut sebagai bahasa di atas bahasa atau metabahasa (metalanguage) (Barthes, 1972:114).

Signifikasi dalam tingkat pertama (language) membentuk tanda yang bersifat denotatif. Tanda denotatif bersifat tetap dan merupakan bahasa yang disepakati oleh masyarakat. Saussure menyatakan bahwa bahasa adalah kesepakatan (convention), hal ini terjadi secara alamiah untuk menanggulangi sifat bahasa yang sebenarnya arbitrer (semena-mena). Misalnya, penanda (signifier) atau aspek material tanda yang terdiri dari huruf "a-n-j-i-n-g", tidak memiliki keharusan untuk terkait dengan konsep mental dalam pikiran atau penanda (signified) yang mengacu pada semacam hewan berkaki empat yang mampu berlari cepat dan bersuara guk-guk. Jadi, karena kesepakatan di masyarakat, kita memaknai kumpulan huruf yang membentuk kata "anjing" sebagai hewan berkaki empat, bersuara $g u k$-guk, dan seterusnya ${ }^{2}$.

Jika sistem signifikasi di tingkat bahasa (language) menunjuk pada makna yang literal atau denotatif, makna dalam sistem signifikasi tingkat mitos (myth) menunjuk pada makna yang bersifat relatif atau konotatif. Barthes sendiri menyebut bahwa selain mitos adalah tingkat kedua dalam sistem signifikasi, mitos juga merupakan sebuah tipe wicara (type of speech) yang terbentuk dari beragam konotasi (Barthes, 1972:122). Maka, untuk membedakannya dengan signifikasi tingkat pertama, penanda tingkat kedua disebut dengan signifier of connotation, atau penanda konotasi, dan petandanya disebut signified of connotation atau petanda konotasi. Dalam hal ini, kita bisa memahami sifat khas dari pembacaan tanda Roland Barthes, bahwa interpretasi tanda harus diperluas ke dalam aspek-aspek konotatif bahasa atau tidak berhenti pada wilayah pemaknaan denotatif semata.

Pembacaan tanda dengan model ini, berpretensi untuk melihat makna-makna tersembunyi atau makna yang sering tak disadari dan diterima begitu saja oleh pembaca awam. Maka itu, mitos dapat dipersamakan dengan ideologi, Barthes sendiri dalam Image Music Text (1977:49) mengatakan bahwa mitos juga merupakan ideologi yang tersusun dari rangkaian petanda konotasi yang disebut sebagai aspek retoris tanda (rhetoric). Persamaan antara mitos dan ideologi juga dikuatkan oleh pembacaan John Storey (2003:8-9), Storey melihat bahwa mitos merupakan bahasa yang dipaksakan untuk diterima dengan tanpa kritik, atau sebuah usaha hegemonik untuk memaksakan makna partikular

\footnotetext{
2 Analogi tentang permainan catur dapat memudahkan kita dalam memahami pandangan Saussure. Sebagai sebuah permainan, catur memiliki aturan-aturan tertentu yang memandu pemainnya untuk menentukan langkahlangkah bidak catur, tiap jenis bidak memiliki aturan langkahnya sendiri. Jadi, sistem permainan catur pasti dan akan selalu mendahului setiap langkah konkret yang diambil oleh seorang pemain catur. Begitu juga dengan bahasa, sistem bahasa (langue) selalui mendahuli praktik ujaran bahasa (parole). Lih. Richard Harland. Superstrukturalisme, Pengantar Komprehensif kepada Semiotika, Strukturalisme dan Post-Strukturalisme (Terj. Iwan Hendrawan). Yogyakarta: Jalasutra. 2006. Hal: 15-16.
} 
menjadi general dan legitimate, sehingga makna dapat diterima dengan seolah-olah terjadi secara alamiah dan wajar adanya.

\section{Mencari Mitos}

Setelah memahami mitos sebagai sebuah tipe wicara dan mitos sebagai tingkat kedua dalam sistem pembacaan tanda. Lantas bagaimanakah kita bisa mencari mitos atau membangun pemaknaan konotatif terhadap tanda yang terdapat dalam berbagai jenis objek?. Untuk menjawabnya kita bisa kembali memahami bahwa Barthes telah memperkenalkan model signifikasi dua tingkat, yakni tingkat bahasa dan tingkat mitos. Tingkat bahasa sebagai tahap signifikasi untuk menemukan makna denotatif, sedangkan tingkat mitos sebagai tahap untuk menemukan makna konotatif atau ideologi di balik objek. Dengan demikian, pemaknaan tanda di dalam teks dalam perspektif semiotika Barthesian pastinya akan dijalankan dalam koridor dua tingkat signifikasi itu.

Kita dapat mengambil contoh paling terkenal tentang bagaimana menerapkan semiotika dua tingkat, dengan melihat bagaimana Barthes memaknai sebuah sampul depan majalah Paris Match bergambar seorang anak negro berseragam sedang berpose hormat pada bendera Prancis ${ }^{3}$. Melalui contoh ini kita bisa menganalisisnya secara sederhana dalam dua tingkat signifikasi. Dimulai dari signifikasi tingkat bahasa (language), gambar anak negro di sampul depan Paris Match itu adalah sebuah penanda (signifier) atau aspek material dari tanda yang berwujud citra-sensoris -bisa juga berbentuk citra-akustik jika itu merupakan bunyi-. Jadi, kita melihat gambar seorang anak negro dalam

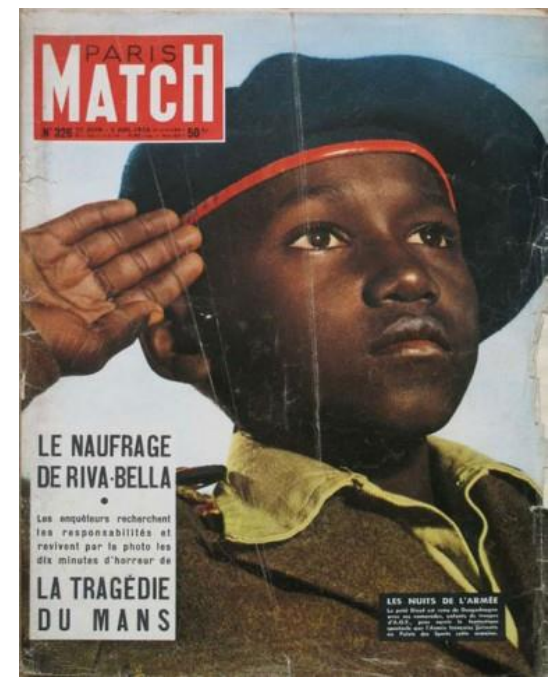
sampul depan itu sebagai penanda yang berupa citra sensoris. Kemudian petanda (signified) atau konsep mental pada penanda ini dalam signifikasi tingkat pertama merujuk pada gagasan bersifat denotatif, maka pentanda dalam objek ini bisa diketahui adalah: seorang anak negro, berseragam, memberi hormat pada bendera Prancis. Maka jelaslah bahwa sampul depan Paris Match dalam edisi ini secara denotatif bermakna, seorang anak negro berseragam yang sedang memberi hormat pada bendera Prancis.

Tanda denotatif dalam signifikasi tingkat pertama yang bermakna : seorang anak negro berseragam Prancis yang sedang memberi hormat, selanjutnya akan dideformasi menjadi penanda konotasi (signifier of connotation) bagi signifikasi tingkat kedua. Setelah memiliki penanda konotasi,

\footnotetext{
${ }^{3}$ Vincent Massen melalui film dokumenternya, Viva Nova (2009), menyelidiki siapa sebenarnya anak negro yang sudah sangat ikonik setelah fotonya dimuat dalam sampul Paris Match, dan oleh Barthes disebut dalam buku Mythologies sebagai kritik atas kolonialisme. Massen menemukan bahwa foto itu diambil dalam sebuah acara festival yang ditayangkan di televisi, Les Nuits de l'Armée (The Nights of the Army) yang digelar tahun 1955. Sosok anak negro itu diketahui adalah Diouf Briane, seorang anak yang ikut dalam festival yang mempertemukan legiun asing Prancis, pasukan pemadam kebakaran, pasukan kulit hitam Dakar (Garde Noire de Dakar) dan anakanak dari tentara Prancis di Afrika Barat. Dalam festival itu mereka merayakan kerajaan kolonial Prancis, tidak salah jika foto anak negro itu, begitu ikonik dalam kritik terhadap kolonialisme. Lih. Lindewey Dovey, Curating Africa in The Age of Film Ferstival, New York: Palgrave Macmillan, 2015. Hal. 76.
} 
signifikasi tingkat mitos membutuhkan petanda konotasi (signified of connotation), sementara petanda konotasi dalam pandangan Barthes merupakan fragmen penyusun ideologi yang sejumlah rangkaiannya bisa disebut aspek retorik dari mitos. Kemunculan petanda-petanda konotasi itulah yang selanjutnya akan mengarahkan kita untuk menemukan mitos di balik objek. Dari penanda konotasi "seorang anak negro berseragam yang sedang memberi hormat pada bendera Prancis ", Barthes kemudian melihat penanda tersebut terkait dengan dua petanda konotasi pokok yaitu "keprancisan" dan "kemiliteran".

Selanjutnya, bagaimana kita bisa menjabarkan mitos jika sudah mendapatkan petanda konotasi, seperti dalam kasus ini yaitu: keprancisan dan kemiliteran?. Untuk menjawabnnya, kita bisa merujuk kembali pada salah satu pengertian mitos dalam pandangan Barthes, bahwa mitos adalah sebuah tipe wicara yang dipilih oleh sejarah (Barthes, 1972:95). Artinya mitos tidak terjadi dengan begitu saja atau alamiah, namun ia terbentuk sebagai sebuah pilihan sejarah, sebagaimana di dalam sejarah itu sendiri di mana segala sesuatu akan berubah karena politik dan gejolak-gejolak tertentu sesuai dengan konteks sosialnya. Karena sifatnya yang tidak alamiah itu, yang membuat mitos memiliki sistem atas nilai-nilai tertentu (system of values), di mana pada kemunculan petanda-petanda konotasi atau fragmen ideologi penyusun wicara mitos selalu terdapat nilai-nilai tertentu yang harus ditelusuri kandungannya dalam bentangan sejarah.

Maka sesungguhnya, petanda-petanda konotasi harus ditempatkan sebagai sesuatu yang tidak bebas nilai. Ia hidup di dalam sejarah yang terhubung dengan ideologi tertentu yang harus dibongkar Gambar.2. Sampul depan Paris dengan melibatkan teks-teks lain. Dalam konteks petanda Match, 25 Juli 1955. www.gettyimages.co.uk konotasi "keprancisan" dan "kemiliteran", mau tidak mau untuk membacanya kita harus membuka literatur sejarah Prancis, kedigdayaan militernya dan bagaimana negara ini membangun sebuah imperium besar yang menguasai tempat tinggal orang-orang Negro $^{4}$. Maka, secara teknis bisa disimpulkan bahwa mitos adalah wicara yang tersusun dari petanda-petanda konotasi yang hidup dalam sejarah. Kita bisa melihat bagaimana Barthes sedikit mengutarakan mitos tentang anak negro yang memberi hormat pada bendera Prancis dalam sampul Paris Match yang telah kita singgung tadi. Barthes menyebut bahwa citra itu mengandung ideologi tentang imperialisme Prancis. Dalam Mythologies (1972:115), ia mengatakan demikian:

"I see very well what it signifies to me: that France is a great Empire, that all her sons, without any colour discrimination, faithfully serve under her flag, and that there is nobetter answer to the detractors of an alleged colonialism than the zeal shown by this Negro in serving his socalled oppressor."

Dari uraian singkat Barthes itu, kita bisa melihat bagaimana ia menunjukkan bahwa gambar dalam sampul Paris Match itu memunculkan mitos tentang Prancis sebagai sebuah imperium besar,

\footnotetext{
${ }^{4}$ Lihat pula contoh yang diberikan oleh Barthes, ketika ia membaca sebuah kalimat dalam bahasa Latin: quia ego nominor leo (because my name is lion). Sepintas tidak ada
} 
dengan segenap putranya yang terlindungi di bawah panji negara tanpa diskriminasi, dan seolah tidak ada jawaban lagi bagi para pengkritik kolonialisme sebab anak Negro itu telah berhormat dengan segenap semangat dan loyalitasnya kepada bendera penindasnya sendiri. Jadi, kita bisa dengan lebih mudah memahami bahwa analisis tingkat mitos dapat berguna untuk membongkar adanya selubung ideologi di balik teks. Seperti dalam kasus anak Negro dalam Paris Match yang mengandung selubung ideologi tentang imperealisme Prancis. Gambar itu seolah menunjukkan kepada pembacanya bahwa penindasan Prancis kepada orang kulit hitam harus diterima dengan suka rela, seolah-olah segala penindasan harus dilupakan dan semua orang harus bersikap suka rela untuk bergabung dalam naungan imperium Prancis.

\begin{tabular}{|l|c|}
\hline \multicolumn{2}{|c|}{ Petanda Konotasi } \\
Seorang anaknegro berseragam yang \\
sedang memberi hormat pada \\
bendera Prancis
\end{tabular}

Tabel .1. Tabel signifikasi tingkat mitos pada sampul depan Paris Match bergambar seorang anak negro yang memberi hormat pada bendera Prancis -interpretasi penulis-.

\section{Melibatkan Pesan Linguistik}

Dalam Rhetoric of The Image, Barthes memberi contoh iklan Panzani, sebuah produk makanan Italia yang terdiri dari dua bungkus pasta, satu kaleng saus dan satu sachet keju, dilengkapi dengan cabe merah, tomat, jamur, dan bawang di dalam keranjang belanja setengah terbuka dengan isinya yang seolah sedang tumpah (Barthes, 1977:33). Untuk menganalisis iklan ini, kiranya akan lebih menguntungkan jika kita melibatkan sebuah konsep yang dipaparkan oleh Barthes (1990:13) dalam $S / Z$, yaitu lexias atau unit-unit pembacaan (units of reading). Konsep lexias akan membantu kita untuk memecah objek menjadi unit-unit kecil, sehingga memudahkan kita untuk melakukan analisis pada masing-masing unit pembacaan tanda.

Kita bisa membaca Barthes dan menemukan ada enam unit pembacaan dari iklan itu. Dua unit berupa pesan linguistik yaitu judul Panzani dan tulisan berbahasa Prancis yang menyebutkan "pasta, saus, keju, dan kemewahan Italia". Empat unit pembacaan lainnya berupa pesan visual, yaitu: "tas setengah terbuka", "pilihan sayuran dan warna merah merona", "makanan Italia", dan "keseluruhan komposisi gambar" (gabungan dari ketiga unit pembacaan sebelumnya). Dalam iklan ini kita telah menemukan pelibatan pesan linguistik berupa judul Panzani, dan capition dalam bahasa Prancis yang 
intinya ingin menunjukkan kemewahan cita rasa Italia. Pesan berupa judul dan caption ini, menurut Barthes bisa disebut sebagai pesan linguistik kategori penambat atau anchorage (Barthes, 1977:39). Fungsi penambat berlaku di mana pesan linguistik berfungsi untuk mengunci keserbamungkinan makna denotatif melalui aktivitas penamaan, yang mana umum ditemuai dalam bentuk judul dan keterangan

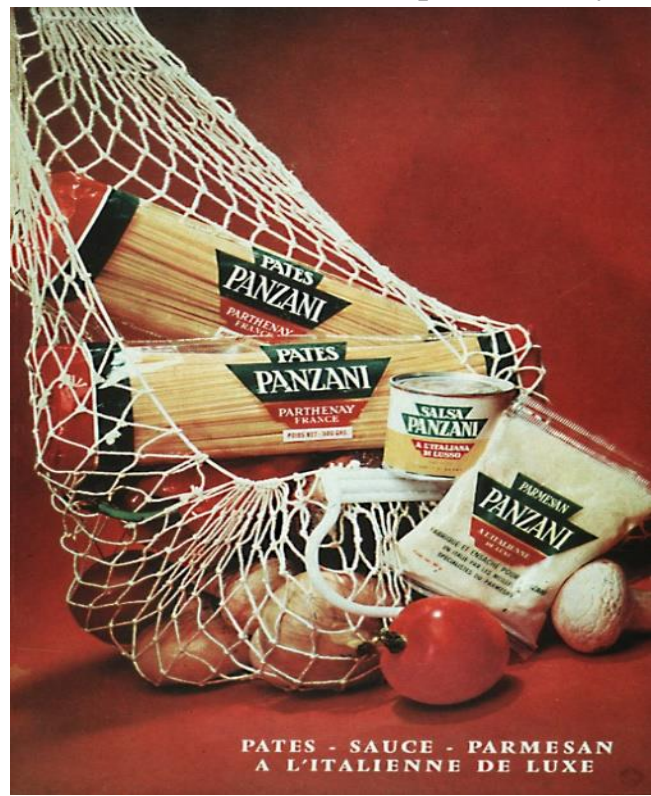
penjelas atau caption. Jadi Melalui pesan linguistik judul iklan Panzani dan caption di bawahnya, kita bisa mengetahui pasti makna denotatif terhadap apa yang dimaksud oleh iklan itu. Jadi, dalam pemaknaan denotatif, kita bisa

memaknai gambar iklan ini dengan: "Iklan makanan Italia dengan merk dagang Panzani berupa pasta, saus, dan keju, di dalam keranjang belanja setengah terbuka bersama sayuran lain, tomat, cabe, jamur dan bawang, yang menunjukkan kemewahan cita rasa Italia”.

Dalam pesan linguistik sebenarnya tidak hanya terdapat pesan berjenis penambat, tetapi ada satu jenis pesan lagi yaitu pesan pemancar atau relay (Barthes, 1977:41). Pesan ini berfungsi dalam hubungan komplementer dengan gambar, umumnya pesan ini berbentuk dialog seperti balon kata dalam komik atau percakapan dalam film, artinya pesan linguistik berfungsi untuk memancarkan makna terhadap gambar. Maka, bisa disimpulkan sementara bahwa dalam analisis semiotika, Barthes menyarankan adanya pelibatan pesan linguistik entah ia berfungsi sebagai pemancar atau penambat, yang keduanya berfungsi untuk menemukan ketepatan makna denotatif suatu tanda.

Setelah kita mengetahui posisi penting pesan linguistik pada proses signifikasi khususnya di tingkat bahasa atau pemaknaan denotasi, marilah kita coba menggali lagi pemaknaan di tingkat mitos dari apa yang sudah dicontohkan Barthes melalui iklan Panzani. Dari gambar itu, kita sudah mendapatkan enam unit pembacaan atau lexia, dua diantaranya berupa pesan linguistik dan empat lainnya berupa pesan visual. Sebelumnya kita sudah mendapati makna denotasi atas iklan itu yang diperoleh dari analisis signifikasi tingkat pertama, selanjutnya akan kita teruskan analisis signifikasi tingkat kedua di level mitos. Tanda denotasi, seperti yang sudah dijelaskan sebelumnya, ia akan dideformasi atau berubah bentuk menjadi penanda konotasi di tingkat mitos.

Mari kita lihat kembali leksia pesan visual "tas setengah terbuka" dan "sayuran di latari warna merah merona". Kita bisa membayangkan seolah-olah jika kita hadir di dalam gambar itu sebagai subjek, kita adalah orang yang baru saja kembali dari pasar. Barangkali dengan agak terburu-buru karena ingin segera memasak dengan bahan makanan segar, kita tidak sengaja menumpahkan barang belanjaan itu. Barthes kemudian menyebut leksia itu mengantarkan pada semacam euforia tentang kesegaran (freshness) dan kegembiraan untuk mempersiapkan masakan di rumah sendiri (domestic preparation). Kemudian leksia "makanan italia" pastinya berhubungan kuat dengan penambat berupa 
judul Panzani dan caption A'Italianne De Luxe (kemewahan Italia), yang secara konotatif mengantarkan imaji kita pada keitalianan (italianicity) yang tercermin dalam kemewahan cita rasa makanannya. Sedangkan pesan visual pada keseluruhan gambar iklan itu, barangkali membuat kita membayangkan betapa produk Panzani menyediakan kemudahan atau kepraktisan bagi anda untuk membuat sendiri masakan dengan cita rasa Italia yang mewah.

Dari upaya analisis di tingkat mitos tadi, kita sudah menemukan beberapa petanda konotasi seperti: keitalianan, kesegaran, keriangan dan kepraktisan memasak, dan kemewahan cita rasa Italia. Petanda-petanda konotasi ini lantas mendorong pemaknaan kita dengan lebih luas untuk menemukan makna terselubung di balik objek iklan Panzani itu. Kita bisa menangkap dengan perbendaharaan petanda konotasi yang kita miliki, bahwa iklan ini berusaha secara halus untuk mengatakan kepada pembaca bahwa Panzani adalah bahan makanan yang praktis, segar, dengan cita rasa Italia yang mewah, dan pastinya membuat anda akan makin gembira dalam memasak. Dari citra itulah kita bisa mencium adanya ideologi di balik objek, di mana terdapat makna yang dipaksakan agar seolah-olah tampak alamiah dan wajar adanya. Dalam konteks iklan Panzani, barangkali kita bisa menyebut adanya pemaksaan dan penyeragaman selera. Dengan Panzani yang menawarkan segala kemudahan dan kemewahan cita rasanya, anda tidak perlu lagi menjalani kerepotan dalam memasak, maka itu anda harus membeli Panzani. Jadi, di balik iklan itu kita bisa menemukan makna tersembunyi misalnya pemaksaan selera dan adanya kepentingan kapital di balik produk-produk makanan instan.

\begin{tabular}{|c|c|c|}
\hline \multirow{2}{*}{$\begin{array}{c}\text { Unit-Unit Pembacaan Tanda } \\
\text { (Lexias) }\end{array}$} & \multicolumn{2}{|c|}{ Signifikasi Mitos } \\
\hline & Penanda Konotasi & Petanda Konotasi \\
\hline Pesan Linguistik & \multirow{8}{*}{$\begin{array}{l}\text { "Iklan makanan Italia dengan } \\
\text { merk dagang Panzani berupa } \\
\text { pasta, saus, dan keju, di dalam } \\
\text { keranjang belanja setengah } \\
\text { terbuka bersama sayuran lain, } \\
\text { tomat, cabe, jamur dan } \\
\text { bawang, yang menunjukkan } \\
\text { kemewahan cita rasa Italia" }\end{array}$} & \multirow{8}{*}{$\begin{array}{l}\text { Keitalianan, } \quad \text { Kesegaran, } \\
\text { Keriangan } \quad \text { Memasak, } \\
\text { Kepraktisan, Kemewahan } \\
\text { cita rasa Italia. }\end{array}$} \\
\hline Panzani & & \\
\hline $\begin{array}{l}\text { Pasta, Saos, } \text { Keju Parma, } \\
\text { Kemewahan Italia }\end{array}$ & & \\
\hline Pesan Visual & & \\
\hline Tas setengah terbuka & & \\
\hline Sayuran dan warna merah merona & & \\
\hline Makanan Italia & & \\
\hline Keseluruhan komposisi gambar & & \\
\hline \multicolumn{3}{|c|}{ Ideologi } \\
\hline & Pemaksaan Selera & \\
\hline
\end{tabular}

Tabel .2. Signifikasi Tingkat Mitos pada Iklan Panzani 


\section{Kesimpulan}

Pemikiran Roland Barthes sebenarnya amat luas dan mencakup berbagai macam objek. Dalam tulisan ini, penulis harus mengakui adanya kekurangan sebab hanya mampu membahas objek sampul majalah dan iklan. Itupun hanya berdasar dari apa yang telah dicontohkan oleh Barthes dalam tulisantulisannya. Akan tetapi, dari bahasan-bahasan di atas paling tidak kita bisa mendapatkan dua poin penting atas analisis semiotika Roland Barthes. Pertama, dalam pembacaan objek visual kita sebaiknya menetapkan adanya unit-unit pembacaan (lexias) untuk mempermudah pembacaan objek ke dalam unitunit tertentu, kemudian kita juga harus memperhatikan kehadiran pesan linguistik yang bisa berfungsi sebagai penambat dan pemancar. Pesan penambat (anchorage) umumnya berupa judul dan caption, sementara pesan pemancar sering ditemukan berupa percakapan seperti dalam film dan komik.

Kedua, analisis semiotika Barthes berada dalam dua tahap analisis, yaitu analisis tingkat bahasa (language) dan analisis tingkat mitos (myth). Analisis tingkat bahasa akan mendasari terbentuknya analisis tingkat mitos, di mana makna denotatif diubah bentuknya menjadi penanda bagi mitos. Sementara dalam analisis tingkat mitos, kita bisa menghubungkan penanda dengan petanda konotatif untuk kemudian mencari ideologi yang terselubung di balik objek. Bagaimana membaca petandapetanda konotatif untuk menemukan ideologi, tentu kita harus menghubungkannya dengan teks-teks lain (intertekstualitas), sejauh mana kita bisa menemukan dan mengkritik adanya ideologi, hal itu sangat tergantung dari bagaimana kedalaman pembacaan kita sendiri untuk mengaitkan petanda-petanda konotasi tentang teks-teks lain.

\section{Daftar Pustaka}

Barthes, Roland. 1968. Elements of Semiology (Trans. Annette Levers and Colin Smith). New York: Hill and Wang.

1972. Mythologies (Trans. Annette Levers). New York: Noonday Press. 1977. Image Music Text (Trans. Stephen Heath). London: Fontana Press. 1981. Camera Lucida, Reflections on Photography (Trans. Richard Howard).

New York: Hill and Wang. 1990. S/Z (Trans. Richard Miller). Oxford: Blacwell.

Budiman, Kris. 2011. Semiotika Visual: Konsep, Isu, dan Problem Ikonisitas. Yogyakarta: Jalasutra.

Sunardi, S.T. 2004. Semiotika Negativa. Yogyakarta: Buku Baik.

Dovey, Lindewey. 2015. Curating Africa in The Age of Film Ferstival. New York: Palgrave Macmillan.

Harland, Richard. 2006. Superstrukturalisme, Pengantar Komprehensif kepada Semiotika, Strukturalisme dan Post-Strukturalisme (Terj. Iwan Hendrawan). Yogyakarta: Jalasutra. Storey, John. 2003. Teori Budaya dan Budaya Pop. (Terj: Dede Nurdin). Yogyakarta: Qalam. 